\title{
PERAMALAN JUMLAH KEDATANGAN WISATAWAN MANCANEGARA KE INDONESIA DENGAN METODE HOLT-WINTERS DAN HUBUNGANNYA TERHADAP PENDAPATAN DEVISA PARIWISATA
}

\author{
Muhammad Aldrin Degasputra Chandrasa ${ }^{1}$, Eman Lesmana², Elis Hertini ${ }^{3}$ \\ 1,2,3 Universitas Padjadjaran, Jl. Raya Bandung Sumedang KM 21 Jatinangor Sumedang, Indonesia \\ Email: aldrin15001@mail.unpad.ac.id
}

\begin{abstract}
Tourism is an important foreign exchange producing sector in Indonesia. In the tourism industry, the accuracy and completeness of good forecasts are required from policymakers and practitioners to prepare the infrastructure, accommodation, and transportation of tourists. The number of tourist arrivals varies each month and arrivals are seasonally patterned so a method is needed that can predict the arrival of tourists precisely. Because tourist arrival data is seasonal and not stationary, holt-winters multiplicative forecasting methods will be used to forecast seasonally patterned arrivals, and will then be searched for forecast results with tourism foreign exchange income. From the results of this study obtained the results of the forecast and relationship with tourism foreign exchange income which then the results can be used as a study material of relevant agencies in taking policies on tourism and the arrival of foreign tourists, such as governments, tour managers, transportation providers, and accommodation providers.
\end{abstract}

Keywords: Forecasting, foreign exchange, holt-winters multiplicative, tourism

\begin{abstract}
ABSTRAK
Pariwisata merupakan sektor penghasil devisa penting di Indonesia. Dalam industri pariwisata, ketepatan dan kelengkapan prakiraan yang baik diperlukan dari pembuat kebijakan dan praktisi untuk mempersiapkan saranaprasarana, akomodasi, dan transportasi wisatawan. Jumlah kedatangan wisatawan yang beragam tiap bulannya dan kedatangan yang berpola musiman sehingga diperlukan metode yang dapat memprediksi kedatangan wisatawan dengan tepat. Karena data kedatangan wisatawan berpola musiman dan tidak stasioner, maka pada artikel ini akan digunakan metode peramalan Holt-Winters multiplikatif untuk meramalkan kedatangan yang berpola musiman, dan kemudian akan dicari hasil ramalan dengan pendapatan devisa pariwisata. Dari hasil penelitian ini didapat hasil ramalan dan hubungan dengan pendapatan devisa pariwisata yang kemudian hasil tersebut dapat digunakan sebagai bahan kajian instansi terkait dalam mengambil kebijakan mengenai pariwisata dan kedatangan wisatawan mancanegara, seperti pemerintah, pengelola tempat wisata, penyedia transportasi, dan penyedia akomodasi.
\end{abstract}

Kata kunci: Devisa, holt-winters multiplikatif, pariwisata, peramalan

Dikirim: 7 Agustus 2020; Diterima: 4 September 2020; Dipublikasikan: 30 September 2020

Cara sitasi: Chandrasa, M. A. D., Lesmana, E., \& Hertini, E. (2020). Peramalan jumlah kedatangan wisatawan mancanegara ke indonesia dengan metode holt-winters dan hubungannya terhadap pendapatan devisa pariwisata. Teorema: Teori dan Riset Matematika, 5(2), 230-238. 


\section{PENDAHULUAN}

Pariwisata merupakan sektor penghasil devisa penting di Indonesia. Menurut kementrian pariwisata, pada tahun 2018 pariwisata menempati urutan kedua dalam hal penerimaan devisa setelah komoditi minyak kelapa sawit. Berdasarkan data tahun 2018, jumlah wisatawan mancanegara yang datang ke Indonesia sebesar 15.806.191 atau tumbuh sebesar 12,58\% dibandingkan tahun sebelumnya.

Dalam industri pariwisata, ketepatan dan kelengkapan prakiraan yang baik diperlukan dari pembuat kebijakan dan praktisi. Sejauh menyangkut aplikasi industri, praktisi pariwisata dapat memeriksa nilai prediksi kedatangan wisatawan dari berbagai sumber dan merencanakan perubahan permintaan dari segmen pasar tertentu dengan memperoleh hasil yang sangat akurat. Jumlah kedatangan wisatawan per bulan pun beragam tiap bulannya dan berpola musiman sehingga diperlukan metode yang dapat memprediksi kedatangan wisatawan dengan pola data musiman.

Industri pariwisata termasuk sumber pendapatan devisa negara yang sangat penting. Sebagai negara wisata, pendapatan dari sektor pariwisata termasuk penghasil pendapatan terbesar. Oleh karena itu, perlu dilihat pengaruh kedatangan wisatawan dengan pendapatan devisa pariwisata. Hal tersebut dilakukan dengan menghitung pendapatan devisa pariwisata berdasarkan hasil ramalan jumlah kedatangan wisatawan mancanegara yang datang ke Indonesia. Metode HoltWinters adalah salah satu metode peramalan yang dapat digunakan untuk meramalkan data berpola musiman.

Pariwisata di Indonesia merupakan salah satu destinasi wisata yang populer dan bidang pariwisata itu sendiri merupakan salah satu sumber penghasil devisa terpenting dan terbanyak. Kedatangan wisatawan tersebut akan mendatangkan penerimaan bagi daerah yang dikunjunginya. Bagi wisatawan yang datang dari luar negeri, kedatangan mereka akan mendatangkan devisa dalam negara. Semakin banyaknya wisatawan berkunjung maka akan memberi dampak yang positif bagi Daerah Tujuan Wisata (DTW) terutama sebagai sumber pendapatan daerah (Qadarrochman, 2010).Oleh karena itu pada penelitian ini akan dilakukan peramalan jumlah kedatangan wisatawan mancanegara ke Indonesia. Hasil ramalan tersebut kemudian akan dicari pengaruhnya terhadap pendapatan devisa negara.

\section{METODE PENELITIAN}

Metode peramalan yang digunakan adalah metode peramalan Holt-Winters. Metode HoltWinters dapat digunakan untuk memprediksi keadaan yang akan datang apabila data hasil ploting mengandung faktor musiman. Metode ini dikembangkan oleh Winters (1960), dengan menambahkan persamaan musiman pada persamaan metode Holt (1957). Metode ini terbagi menjadi dua, yaitu aditif dan multiplikatif berdasarkan pola yang ditunjukkan oleh plot data musiman.

Metode Holt-Winters Aditif digunakan ketika variasi musiman cenderung konstan pada deret waktu. Adapun modelnya adalah sebagai berikut (Emmanuel et al., 2014).

Pemulusan keseluruhan (level):

$$
L_{t}=\alpha\left(X_{t}-S_{t-c}\right)+(1-\alpha)\left(L_{t-1}+T_{t-1}\right)
$$

Pemulusan kecenderungan (trend):

Pemulusan musiman:

$$
T_{t}=\beta\left(L_{t}-L_{t-1}\right)+(1-\beta) T_{t-1}
$$

$$
S_{t}=\gamma\left(X_{t}-L_{t}\right)+(1-\gamma) S_{t-c}
$$

Persamaan hasil ramalan untuk $k$ period ke depan:

$$
F_{t+k}=L_{t}+k T_{t}+S_{t+k-c}
$$

Metode Holt-Winters multiplikatif digunakan ketika variasi musiman berfluktuasi pada deret waktu. Adapun modelnya adalah sebagai berikut (Emmanuel et al., 2014). 
Pemulusan keseluruhan (level):

$$
L_{t}=\alpha \frac{x_{t}}{s_{t-c}}+(1-\alpha)\left(L_{t-1}+T_{t-1}\right)
$$

Pemulusan kecenderungan (trend):

Pemulusan musiman:

$$
T_{t}=\beta\left(L_{t}-L_{t-1}\right)+(1-\beta) T_{t-1}
$$

$$
S_{t}=\gamma \frac{X_{t}}{L_{t}}+(1-\gamma) S_{t-c}
$$

Persamaan hasil ramalan untuk $k$ periode ke depan:

Keterangan:

$$
F_{t+k}=\left(L_{t}+k T_{t}\right) S_{t+k-c}
$$

$\alpha=$ Parameter pemulusan relatif dengan pegamatan stasioner yang baru dilakukan yang nilainya terletak diantara 0 dan 1

$\beta=$ Parameter pemulusan relatif dengan estimasi kemunculan unsur trend yang nilainya terletak diantara 0 dan 1

$\gamma=$ Parameter pemulusan relatif dengan estimasi kemunculan unsur musiman yang nilainya terletak diantara 0 dan 1

$c=$ Panjang musiman

$L_{t}=$ Pemulusan keseluruhan untuk periode $t$

$T_{t}=$ Pemulusan trend untuk periode $t$

$S_{t}=$ Pemulusan musiman untuk periode $t$

Metode Holt-Winters memerlukan nilai inisialisasi untuk setiap nilai pemulusan. Untuk menentukan nilai inisialisasi tersebut dapat digunakan model berikut.

$$
\begin{gathered}
L_{c}=\frac{1}{c}\left(X_{1}+X_{2}+X_{3}+\cdots+X_{c}\right) \\
T_{c}=\frac{1}{c}\left(\frac{X_{c+1}-X_{1}}{c}+\frac{X_{c+2}-X_{2}}{c}+\frac{X_{c+3}-X_{3}}{c}+\cdots+\frac{X_{2 c}-X_{c}}{c}\right)
\end{gathered}
$$

Model tersebut dapat digunakan untuk Holt-Winters aditif dan multiplikatif. Untuk mencari nilai $S_{t}$ dapat digunakan:

untuk Holt-Winters aditif, dan

$$
S_{t}=X_{t}-L_{c} ; t=1,2,3, \ldots, c
$$

$$
S_{t}=\frac{X_{t}}{L_{c}} ; t=1,2,3, \ldots, c
$$

untuk Holt-Winters multiplikatif.

Mean Absolute Precentage Error (MAPE) merupakan ukuran ketepan relatif yang digunakan untuk mengetahui persentase penyimpangan hasil peramalan (Sungkawa \& Megasari, 2011). Persamaannya adalah sebagai berikut.

$$
M A P E=\frac{1}{n} \sum_{t=1}^{n}\left|\left(\frac{x_{t}-F_{t}}{x_{t}}\right) \times 100 \%\right|
$$

\section{Hasil dan Pembahasan}

Data yang digunakan adalah data kunjungan wisatawan mancanegara yang datang pada bulan Januari 2016 sampai dengan Desember 2019 yang disajikan pada Tabel 1. 
Tabel 1. Data aktual jumlah wisatawan mancanegara yang berkunjung ke Indonesia melalui 14 pintu utama (orang)

\begin{tabular}{cccccc}
\hline Periode $(\mathbf{t})$ & Waktu & Data & Periode $(\mathrm{t})$ & Waktu & Data \\
\hline 1 & Jan-16 & 581932 & 25 & Jan-18 & 685540 \\
2 & Feb-16 & 636881 & 26 & Feb-18 & 792716 \\
3 & Mar-16 & 672108 & 27 & Mar-18 & 902569 \\
4 & Apr-16 & 678234 & 28 & Apr-18 & 894884 \\
5 & May-16 & 700669 & 29 & May-18 & 854320 \\
6 & Jun-16 & 654944 & 30 & Jun-18 & 871531 \\
7 & Jul-16 & 819074 & 31 & Jul-18 & 1133766 \\
8 & Aug-16 & 834797 & 32 & Aug-18 & 1079891 \\
9 & Sep-16 & 800663 & 33 & Sep-18 & 982156 \\
10 & Oct-16 & 792592 & 34 & Oct-18 & 920198 \\
11 & Nov-16 & 740402 & 35 & Nov-18 & 778553 \\
12 & Dec-16 & 789637 & 36 & Dec-18 & 908103 \\
13 & Jan-17 & 789687 & 37 & Jan-19 & 762135 \\
14 & Feb-17 & 751543 & 38 & Feb-19 & 801148 \\
15 & Mar-17 & 785821 & 39 & Mar-19 & 844381 \\
16 & Apr-17 & 855245 & 40 & Apr-19 & 844179 \\
17 & May-17 & 846691 & 41 & May-19 & 788668 \\
18 & Jun-17 & 810747 & 42 & Jun-19 & 916596 \\
19 & Jul-17 & 1047550 & 43 & Jul-19 & 1042199 \\
20 & Aug-17 & 1066588 & 44 & Aug-19 & 1054454 \\
21 & Sep-17 & 930011 & 45 & Sep-19 & 969016 \\
22 & Oct-17 & 848771 & 46 & Oct-19 & 920968 \\
23 & Nov-17 & 745610 & 47 & Nov-19 & 845981 \\
24 & Dec-17 & 728536 & 48 & Dec-19 & 921305 \\
\hline
\end{tabular}

Sumber : Badan Pusat Statistik

Pola dari data Tabel 1 lebih lanjut dijelaskan pada Gambar 1.

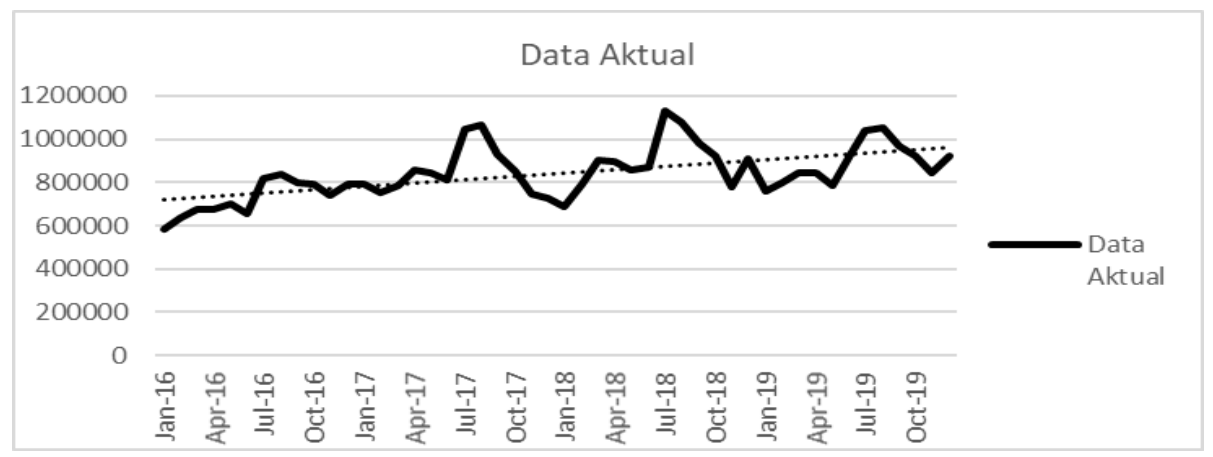

Gambar 1. Grafik kedatangan wisatawan mancanegara ke Indonesia

Berdasarkan Gambar 1 dapat dilihat bahwa data kedatangan wisatawan mancanegara ke Indonesia memiliki kecenderungan (trend) naik atau bisa dikatakan tidak stasioner. Untuk memastikan ketidak stasioneran data maka dilakukan uji stasioneritas menggunakan uji akar unit. Pengujian dilakukan menggunakan aplikasi eviews 9 dengan menggunakan uji Dickey-Fuller. Hasil pengujiannya disajikan pada Tabel 2.

Tabel 2. Hasil uji akar unit

Null Hypothesis: KEDATANGAN_WISATAWAN has a unit root

Exogenous: Constant

Lag Length: 0 (Automatic - based on SIC, maxlag=9)

\begin{tabular}{lccc}
\hline \hline & t-Statistic & Prob. $^{*}$ \\
\hline \hline \multicolumn{2}{l}{ Augmented Dickey-Fuller test statistic } & -3.122393 & 0.0316 \\
\hline Test critical values: & $1 \%$ level & -3.577723 & \\
& $5 \%$ level & -2.925169 & \\
$10 \%$ level & -2.600658 & \\
\hline \hline
\end{tabular}

*MacKinnon (1996) one-sided p-values. 
Berdasarkan hasil uji akar terlihat bahwa dengan $\alpha=0.01, H_{0}: \delta=0$ diterima, karena nilai uji statistic ADF adalah -3.122393 , nilai titik kritis pada taraf signifikansi $(\alpha) 1 \%$ adalah -3.57723 , dan $|-3.122393|<|-3.57723|$. Dengan demikian dapat disimpulkan bahwa data kedatangan wisatawan mancanegara bersifat tidak stasioner.

Langkah selanjutnya adalah menguji unsur musiman dengan membandingkan nilai individu dengan rata-rata untuk tiap musim. Pengujian unsur musiman dapat dilihat pada Tabel 3.

Tabel 3. Pengujian unsur musiman data jumlah wisatawan mancanegara yang berkunjung ke Indonesia (orang)

\begin{tabular}{cccccc}
\hline \multirow{2}{*}{ Periode } & \multirow{2}{*}{ Bulan } & $\mathbf{2 0 1 6}$ & $\mathbf{2 0 1 7}$ & $\mathbf{2 0 1 8}$ & $\mathbf{2 0 1 9}$ \\
\hline 1 & Januari & 581932 & 789687 & 685540 & 762135 \\
2 & Februari & 636881 & 751543 & 792716 & 801148 \\
3 & Maret & 672108 & 785821 & 902569 & 844381 \\
4 & April & 678234 & 855245 & 894884 & 844179 \\
5 & Mei & 700669 & 846691 & 854320 & 788668 \\
6 & Juni & 654944 & 810747 & 871531 & 916596 \\
7 & Juli & 819074 & 1047550 & 1133766 & 1042199 \\
8 & Agustus & 834797 & 1066588 & 1079891 & 1054454 \\
9 & September & 800663 & 930011 & 982156 & 969016 \\
10 & Oktober & 792592 & 848771 & 920198 & 920968 \\
11 & November & 740402 & 745610 & 778553 & 845981 \\
12 & Desember & 789637 & 728536 & 908103 & 921305 \\
& Total & 8701933 & 10206800 & 10804227 & 10711030 \\
& Rata-rata & 725161,1 & 850566,7 & 900352,3 & 892585,8 \\
\hline
\end{tabular}

Dari Tabel 3 bisa dilihat bahwa pada periode 7, 8, dan 9 pada tiap musim yaitu pada bulan Juli, Agustus, dan September data kedatangan melebihi nilai rata-rata musimnya, sedangkan pada periode 1 dan 2 yaitu bulan Januari dan Februari data kedatangan lebih kecil dari nilai rata-ratanya. Berdasarkan hal tersebut dapat ditarik kesimpulan bahwa data kedatangan wisatawan mancanegara mempunyai unsur musiman dengan panjang periode musimannya 12 bulan. Karena data tidak stasioner dan memiliki unsur musiman maka metode yang tepat untuk meramalkan dari data tersebut adalah metode Holt-Winters multiplikatif.

Untuk meramalkan data menggunakan metode Holt-Winters akan dilakukan langkahlangkah berikut (Emmanuel et al., 2014).

1. Menghitung nilai inisialisasi

Langkah ini menghitung nilai pemulusan Level untuk periode $12\left(L_{12}\right)$, nilai pemulusan Trend untuk periode $12\left(T_{12}\right)$, dan nilai pemulusan musiman periode $1\left(S_{1}\right)$ sampai periode $12\left(S_{12}\right)$.

Dengan menggunakan persamaan (9), diperoleh hasil $L_{12}$ adalah 765161.1. Dengan menggunakan persamaan (10) diperoleh nilai $T_{12}$ adalah 109535.4. Dengan menggunakan persamaan (11) diperoleh nilai $S_{1}$ sampai $S_{12}$ pada Tabel 4.

Tabel 4. Hasil perhitungan $S_{13}$ sampai $S_{48}$

\begin{tabular}{cccc}
\hline Periode $(\mathrm{t})$ & $S_{\mathrm{t}}$ & Periode $(\mathrm{t})$ & $S_{\mathrm{t}}$ \\
\hline 1 & 0.802487 & 7 & 1.129506 \\
2 & 0.878261 & 8 & 1.151188 \\
3 & 0.92684 & 9 & 1.104117 \\
4 & 0.935287 & 10 & 1.092988 \\
5 & 0.966225 & 11 & 1.021017 \\
6 & 0.90317 & 12 & 1.088913 \\
\hline
\end{tabular}

2. Menghitung nilai lanjutan

Langkah ini diawali dengan menentukan nilai-nilai parameter $\alpha, \beta$, dan $\gamma$ yang meminimumkan nilai MAPE. Setelah dilakukan perhitungan dengan aplikasi Microsoft Excel, diperoleh nilai-nilai parameter $\alpha$ adalah $0.9999, \beta$ adalah 0.4230 , dan $\gamma$ adalah 0.0610 . 
Langkah selanjutnya adalah mencari nilai nilai pemulusan level $\left(L_{t}\right)$ untuk periode 13 sampai dengan periode 48. Dengan menggunaan persamaan (5) hasilnya disajikan pada Tabel 5.

Tabel 5. Hasil perhitungan $L_{13}$ sampai $L_{48}$

\begin{tabular}{cccccc}
\hline Periode $(\mathbf{t})$ & $\boldsymbol{L}_{\boldsymbol{t}}$ & Periode $(\mathbf{t})$ & $\boldsymbol{L}_{\boldsymbol{t}}$ & Periode $(\mathbf{t})$ & $\boldsymbol{L}_{\boldsymbol{t}}$ \\
\hline 13 & 984048.7 & 25 & 854267.3 & 37 & 949716.7 \\
14 & 855719.8 & 26 & 902597.1 & 38 & 912197.8 \\
15 & 847850.6 & 27 & 973813.4 & 39 & 911032.5 \\
16 & 914419 & 28 & 956801.9 & 40 & 902587.9 \\
17 & 876288.1 & 29 & 884184 & 41 & 816236.2 \\
18 & 897667.7 & 30 & 964967.6 & 42 & 1014865 \\
19 & 927440.4 & 31 & 1003771 & 43 & 922703.3 \\
20 & 926510.6 & 32 & 938067.3 & 44 & 915970 \\
21 & 842312.6 & 33 & 889539.9 & 45 & 877638.6 \\
22 & 776560.9 & 34 & 841911 & 46 & 842615.3 \\
23 & 730261.9 & 35 & 762527.2 & 47 & 828566.8 \\
24 & 669049.3 & 36 & 833952.8 & 48 & 846078
\end{tabular}

Langkah selanjutnya adalah menghitung nilai pemulusan Trend $\left(T_{t}\right)$ untuk periode 13 sampai 48. Dengan menggunakan persamaan (6) hasilnya dapat dilihat pada Tabel 6.

Tabel 6. Hasil perhitungan $T_{13}$ sampai $T_{36}$

\begin{tabular}{cccccc}
\hline Periode $(\mathbf{t})$ & $\boldsymbol{T}_{\boldsymbol{t}}$ & Periode $(\mathbf{t})$ & $\boldsymbol{T}_{\boldsymbol{t}}$ & Periode $(\mathbf{t})$ & $\boldsymbol{T}_{\boldsymbol{t}}$ \\
\hline 13 & 175314.5 & 25 & 51992.61 & 37 & 48442.67 \\
14 & 41580.96 & 26 & 50379.38 & 38 & 12079.78 \\
15 & 19801.63 & 27 & 59556.59 & 39 & 6476.972 \\
16 & 40399.14 & 28 & 25833.7 & 40 & 164.9213 \\
17 & 5812.171 & 29 & -17527.3 & 41 & -36432.7 \\
18 & 12668.52 & 30 & 25771.72 & 42 & 63001.25 \\
19 & 20201.73 & 31 & 31511.35 & 43 & -2634.59 \\
20 & 10894.77 & 32 & -11305.1 & 44 & -4368.39 \\
21 & -30986.9 & 33 & -27698.9 & 45 & -18735.2 \\
22 & -46298.4 & 34 & -36476.6 & 46 & -25625.3 \\
23 & -46298.7 & 35 & -55374.3 & 47 & -20728.2 \\
24 & -52867.2 & 36 & 472.1574 & 48 & -4552.4 \\
\hline
\end{tabular}

Langkah selanjutnya adalah menghitung nilai pemulusan musiman $\left(S_{t}\right)$ untuk periode 13 sampai 48. Dengan menggunakan persamaan (7) hasilnya disajikan pada Tabel 7.

Tabel 7. Hasil perhitungan $S_{13}$ sampai $S_{48}$

\begin{tabular}{cccccc}
\hline Periode $(\mathbf{t})$ & $\boldsymbol{S}_{\boldsymbol{t}}$ & Periode $(\mathbf{t})$ & $\boldsymbol{S}_{\boldsymbol{t}}$ & Periode $(\mathbf{t})$ & $\boldsymbol{S}_{\boldsymbol{t}}$ \\
\hline 13 & 0.802487 & 25 & 0.802487 & 37 & 0.802487 \\
14 & 0.878261 & 26 & 0.878261 & 38 & 0.878261 \\
15 & 0.92684 & 27 & 0.92684 & 39 & 0.92684 \\
16 & 0.935287 & 28 & 0.935287 & 40 & 0.935287 \\
17 & 0.966225 & 29 & 0.966225 & 41 & 0.966225 \\
18 & 0.90317 & 30 & 0.90317 & 42 & 0.90317 \\
19 & 1.129506 & 31 & 1.129506 & 43 & 1.129506 \\
20 & 1.151188 & 32 & 1.151188 & 44 & 1.151188 \\
21 & 1.104117 & 33 & 1.104117 & 45 & 1.104117 \\
22 & 1.092987 & 34 & 1.092987 & 46 & 1.092987 \\
23 & 1.021017 & 35 & 1.021017 & 47 & 1.021017 \\
24 & 1.088913 & 36 & 1.088913 & 48 & 1.088913 \\
\hline
\end{tabular}

3. Menghitung hasil ramalan.

Langkah terakhir setelah memperoleh lanjutan adalah menghitung hasil ramalan untuk periode 13 sampai 48. Dengan menggunakan persamaan (8) hasilnya disajikan pada Tabel 8. 
Tabel 8. Hasil perhitungan $F_{13}$ sampai $F_{48}$

\begin{tabular}{cccccc}
\hline Periode $(\mathbf{t})$ & $\boldsymbol{F}_{\boldsymbol{t}}$ & Periode $(\mathbf{t})$ & $\boldsymbol{F}_{\boldsymbol{t}}$ & Periode $(\mathbf{t})$ & $\boldsymbol{F}_{\boldsymbol{t}}$ \\
\hline 13 & 669832.7 & 25 & 495145.4 & 37 & 668504.5 \\
14 & 1015941 & 26 & 792715.7 & 38 & 876644.9 \\
15 & 835160.5 & 27 & 881354 & 39 & 856657 \\
16 & 814353.4 & 28 & 965051.3 & 40 & 858135 \\
17 & 923481.8 & 29 & 949872.5 & 41 & 872262.6 \\
18 & 798412.9 & 30 & 784516.1 & 42 & 704295.4 \\
19 & 1029171 & 31 & 1118397 & 43 & 1217456 \\
20 & 1091125 & 32 & 1191161 & 44 & 1059172 \\
21 & 1035528 & 33 & 1024766 & 45 & 1006515 \\
22 & 888876.2 & 34 & 943553.7 & 46 & 938770.6 \\
23 & 747365.2 & 35 & 823564.5 & 47 & 834161 \\
24 & 745856.1 & 36 & 771580.7 & 48 & 879665.6 \\
\hline
\end{tabular}

Berdasarkan hasil peramalan tersebut diperoleh nilai MAPE sebesar $5.8498 \%$. Kemudian selanjutnya adalah melakukan peramalan yang dilakukan sampai 2 tahun kedepan yaitu dari Januari 2020 sampai Desember 2021. Hasil ramalan disajikan pada Tabel 9.

Tabel 9. Hasil ramalan kedatangan wisatawan mancanegara (orang)

\begin{tabular}{cccccc}
\hline Periode & Waktu & Hasil Ramalan & Periode & Waktu & Hasil Ramalan \\
\hline 49 & Jan-20 & 675312.98 & 61 & Jan-21 & 631474.09 \\
50 & Feb-20 & 735081.25 & 62 & Feb-21 & 687102.86 \\
51 & Mar-20 & 771520.55 & 63 & Mar-21 & 720888.39 \\
52 & Apr-20 & 774294.85 & 64 & Apr-21 & 723201.2 \\
53 & May-20 & 795508.75 & 65 & May-21 & 742725 \\
54 & Jun-20 & 739483.03 & 66 & Jun-21 & 690143.9 \\
55 & Jul-20 & 919656.65 & 67 & Jul-21 & 857953.05 \\
56 & Aug-20 & 932069.77 & 68 & Aug-21 & 869181.71 \\
57 & Sep-20 & 888931.99 & 69 & Sep-21 & 828615.36 \\
58 & Oct-20 & 874995.5 & 70 & Oct-21 & 815286.88 \\
59 & Nov-20 & 812731.37 & 71 & Nov-21 & 756954.4 \\
60 & Dec-20 & 861818.95 & 72 & Dec-21 & 802332.94 \\
\hline
\end{tabular}

Untuk melihat hubungan hasil ramalan kedatangan wisatawan mancanegara dengan pendapatan devisa pariwisata, akan dilihat proyeksi hasil ramalan tahun 2020 sampai 2021 dan perbandingan dengan data aktual tahun-tahun sebelumnya. Data tersebut disajikan pada Tabel 10.

Tabel 10. Kedatangan wisatawan mancanegara per tahun (orang)

\begin{tabular}{ccccccc}
\hline Tahun & 2016 & 2017 & 2018 & 2019 & $\begin{array}{c}\text { 2020 } \\
\text { (Ramalan) }\end{array}$ & $\begin{array}{c}\text { 2021 } \\
\text { (Ramalan) }\end{array}$ \\
\hline $\begin{array}{c}\text { Jumlah } \\
\text { Kedatangan }\end{array}$ & 8701933 & 10206800 & 10804227 & 10711030 & 9781406 & 9125860 \\
\hline
\end{tabular}

Untuk menghitung devisa wisatawan mancanegara tahun 2016-2021, akan digunakan data Jumlah Wisatawan Asing, Devisa Wisman, dan Tingkat Penghunian Kamar (TPK) Hotel Bintang dan Non Bintang Tahun 2002-2015 untuk mencari devisa yang dihasilkan per wisatawan, yaitu dengan membagi devisa yang dihasilkan di tahun tersebut dengan jumlah wisatawan yang menginap. Data tersebut disajikan pada Tabel 11.

Tabel 11. Jumlah wisatawan asing, devisa wisman, dan tingkat penghunian kamar (tpk) hotel bintang dan non bintang tahun 2002-2015

\begin{tabular}{ccccccc}
\hline Tahun & $\begin{array}{c}\text { Jumlah } \\
\text { Wisatawan } \\
\text { (Orang) }\end{array}$ & $\begin{array}{c}\text { Devisa } \\
\text { Wisman (Juta } \\
\text { US\$) }\end{array}$ & $\begin{array}{c}\text { Hotel } \\
\text { Bintang }\end{array}$ & $\begin{array}{c}\text { Hotel Non } \\
\text { Bintang }\end{array}$ & $\begin{array}{c}\text { Total } \\
\text { Bintang+Non } \\
\text { Bintang }\end{array}$ & $\begin{array}{c}\text { Devisa Per } \\
\text { Wisatawan } \\
\text { (US\$) }\end{array}$ \\
\hline 2002 & 5033400 & 4305.56 & 44.28 & 30.57 & 74.85 & 1142.816221 \\
2003 & 4467021 & 4037.02 & 45.03 & 29.88 & 74.91 & 1206.432727 \\
2004 & 5321165 & 4797.88 & 44.98 & 28.33 & 73.31 & 1229.927285 \\
2005 & 5002101 & 4521.9 & 45.03 & 28.86 & 73.89 & 1223.440437 \\
\hline
\end{tabular}


Lanjutan Tabel 11.

Tabel 11. Jumlah wisatawan asing, devisa wisman, dan tingkat penghunian kamar (tpk) hotel bintang dan non bintang tahun 2002-2015

\begin{tabular}{|c|c|c|c|c|c|c|}
\hline \multirow[b]{2}{*}{ Tahun } & \multirow[b]{2}{*}{$\begin{array}{c}\text { Jumlah } \\
\text { Wisatawan } \\
\text { (Orang) }\end{array}$} & \multirow[b]{2}{*}{$\begin{array}{c}\text { Devisa } \\
\text { Wisman (Juta } \\
\text { US\$) }\end{array}$} & \multicolumn{3}{|c|}{ Tingkat Hunian Kamar (\%) } & \multirow[b]{2}{*}{$\begin{array}{c}\text { Devisa Per } \\
\text { Wisatawan } \\
\text { (US\$) }\end{array}$} \\
\hline & & & $\begin{array}{c}\text { Hotel } \\
\text { Bintang }\end{array}$ & $\begin{array}{c}\text { Hotel Non } \\
\text { Bintang }\end{array}$ & $\begin{array}{c}\text { Total } \\
\text { Bintang+Non } \\
\text { Bintang }\end{array}$ & \\
\hline 2006 & 4871351 & 4447.98 & 46.19 & 29.8 & 75.99 & 1201.591806 \\
\hline 2007 & 5505759 & 5345.98 & 46.89 & 32.44 & 79.33 & 1223.975368 \\
\hline 2008 & 6234497 & 7347.6 & 48.06 & 34.65 & 82.71 & 1424.905505 \\
\hline 2009 & 6323730 & 6297.99 & 48.31 & 35.56 & 83.87 & 1187.468245 \\
\hline 2010 & 7002944 & 7603.45 & 48.86 & 35.98 & 84.84 & 1279.762503 \\
\hline 2011 & 7649731 & 8554.39 & 51.25 & 38.74 & 89.99 & 1242.649446 \\
\hline 2012 & 8044462 & 9120.89 & 51.55 & 38.22 & 89.77 & 1263.016396 \\
\hline 2013 & 8802129 & 10054.15233 & 52.22 & 37.34 & 89.55 & 1275.506271 \\
\hline 2014 & 9435411 & 11166.13406 & 52.56 & 35.87 & 88.43 & 1338.291558 \\
\hline \multirow[t]{2}{*}{2015} & 10230775 & 12225.89 & 53.91 & 33.21 & 87.13 & 1371.498234 \\
\hline & & & \multicolumn{2}{|c|}{ Rata-rata } & 82.04086 & 1257.948715 \\
\hline
\end{tabular}

Berdasarkan Tabel 11 diperoleh bahwa wisatawan mancanegara yang datang ke Indonesia rata-rata berkontribusi sebesar $\$ 1257.948715$ per wisatawan, dengan rata-rata tingkat wisatawan mancanegara yang menginap sebesar $82.04086 \%$ baik di hotel bintang maupun non bintang. Hasil tersebut akan digunakan untuk menghitung jumlah devisa wisatawan mancanegara di tahun 2016 2021, yaitu dihitung menggunakan persamaan berikut.

Jumlah Pendapatan Devisa $=[$ (Jumlah wisatawan $) \times$

(rata-rata tingkat wisatawan yang menginap)] $\times$

(rata-rata devisa per wisatawan)

Hasil perhitungan tersebut disajikan pada Tabel 12.

Tabel 12. Hasil perhitungan pendapatan devisa wisatawan mancanegara tahun 2016-2021

\begin{tabular}{ccc}
\hline Tahun & Jumlah Wisatawan (Orang) & $\begin{array}{c}\text { Jumlah Pendapatan Devisa } \\
\text { Wisman (Juta US\$) }\end{array}$ \\
\hline 2016 & 8701933 & 8980.673 \\
2017 & 10206800 & 10533.74 \\
2018 & 10804227 & 11150.31 \\
2019 & 10711030 & 11054.13 \\
2020 & 9781406 & 10094.72 \\
2021 & 9125860 & 9418.179 \\
\hline
\end{tabular}

Berdasarkan hasil ramalan kedatangan wisatawan mancanegara per tahunnya bisa dilihat bahwa kedatangan pada tahun 2020-2021 diprediksi mengalami penurunan. Pada tahun 2020 kedatangan diramalkan sebanyak 9781406 wisatawan, menurun sebesar $8.68 \%$ dari tahun sebelumnya. Kedatangan pada tahun 2021 diramalkan akan menurun dibandingkan tahun 2020.

Berdasarkan hasil perhitungan hubungan kedatangan wisatawan mancanegara dengan pendapatan devisa dapat dilihat bahwa ketika jumlah wisatawan meningkat dari tahun sebelumnya, maka jumlah pendapatan devisa yang diperoleh dari wisatawan pun meningkat. Ketika kedatangan wisatawan pada tahun 2019 menurun dibandingkan tahun 2018, perolehan devisanya pun ikut menurun. Berlaku pula sebaliknya apabila pada tahun tersebut jumlah wisatawan menurun dari tahun sebelumnya, maka jumlah pendapatan devisa pun ikut menurun.

\section{KESIMPULAN}

Berdasarkan hasil ramalan, kedatangan wisatawan mancanegara ke Indonesia tahun 20202021 menunjukkan kecenderungan menurun. Penurunan ini disebabkan oleh keadaan data aktual tahun sebelumnya yang juga menurun. Penurunan per tahun dipengaruhi penurunan kedatangan wisatawan pada bulan-bulan musim liburan, yaitu Juli, Agustus, dan September. Berdasarkan analisis hasil ramalan kedatangan wisatawan mancanegara ke Indonesia tahun 2020-2021, 
pendapatan devisa wisatawan mancanegara diprediksikan mengalami penurunan. Karena kedatangan wisatawan juga menurun, dapat disimpulkan bahwa kedatangan wisatawan mancanegara berbanding lurus dengan pendapatan devisa pariwisata. Untuk meningkatkan pendapatan devisa pariwisata maka perlu mengembangkan bidang pariwisata.

\section{REKOMENDASI}

Metode peramalan yang digunakan untuk meramalkan data musiman pada penelitian ini adalah peramalan Holt-Winters. Pada penelitian selanjutnya dapat menggunakan metode peramalan lainnya yang dapat meramalkan data musiman seperti metode dekomposisi dan metode fuzzy untuk mengetahui metode yang lebih tepat dalam meramalkan data musiman kedatangan pariwisata.

Penelitian ini menggunakan asumsi bahwa devisa wisatawan mancanegara yang dihasilkan bergantung pada rata-rata kontribusi devisa per wisatawan mancanegara yang datang ke Indonesia. Untuk penelitian selanjutnya dapat melakukan perhitungan faktor-faktor lain yang dapat mempengaruhi pendapatan devisa pariwisata agar dapat mempertimbangkan faktor-faktor tersebut dalam pengambilan kebijakan. Menurut Huda (2009), jumlah wisatawan, objek wisata, jumlah hotel, biro perjalanan, rata-rata lama tinggal, rata-rata pengeluaran wisatawan, dan kurs dollar AS berpengaruh signifikan terhadap penerimaan devisa sektor pariwisata.

Untuk pihak terkait disarankan untuk dapat mengembangkan pariwisata Indonesia dengan meningkatkan kedatangan wisatawan mancanegara ke Indonesia. Cara yang dapat dilakukan adalah menggencarkan promosi objek wisata yang ada di Indonesia.

\section{DAFTAR PUSTAKA}

Badan Pusat Statistik. (2019). Dipetik dari https://www.bps.go.id/subject/16/pariwisata.html

Emmanuel, O. O., Adebanji, A., \& Labeodan, O. (2014). Using holt winter's multiplicative model to forecast assisted chillbirths at the teaching hospital in ashanti region. Ghana. Journal of Biology, Agriculture, and Healthcare, 4(9).

Holt, C.C. (1957). Forecasting seasonals and trends by exponentially weighted moving averages. ONR Memorandum, 52, Carnegie Institute of Technology, Pittsburgh.

Huda, S. (2009). Analisis penerimaan devisa sektor pariwisata dan faktor-faktor yang mempengaruhi di provinsi jawa timur. Surabaya: Universitas Pembangunan Nasional "Veteran".

Qadarrochman, N. (2010). Analisis penerimaan daerah dari sektor pariwisata di kota semarang dan faktor-faktor yang mempengaruhinya. Skripsi. Semarang: Universitas Diponogoro.

Republik Indonesia. (2009). Undang-Undang Republik Indonesia Nomor 10 Tahun 2009 Tentang Kepariwisataan. Lembarang Negara Republik Indonesia Tahun 2009 Nomor 11. Sekretariat Negara Indonesia. Jakarta.

Sungkawa, I., \& Megasari, R. T. (2011). Penerapan ukuran ketepatan nilai ramalan data deret waktu dalam seleksi model peramalan volume penjualan pt satriamandiri citramulia. Jakarta: Binus University.

Winters, P. R. (1960). Forecasting sales by exponentially weighted moving averages. Jurnal Management Science, 6(3). 